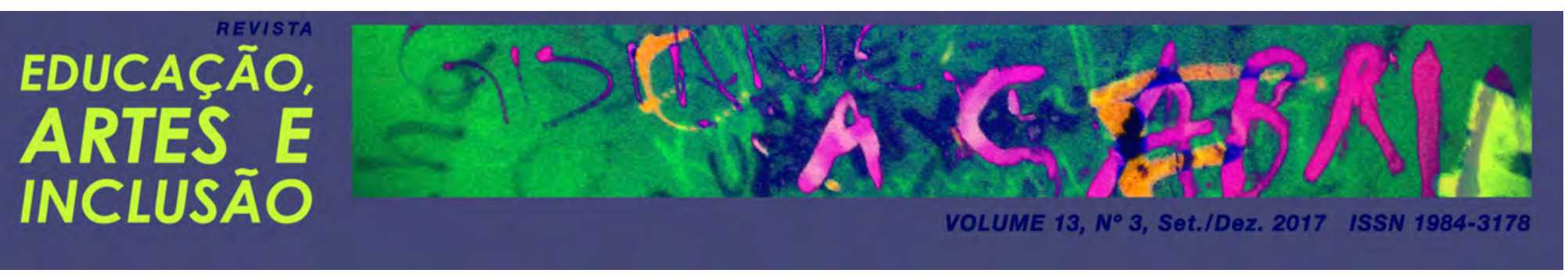

\title{
EDUCAÇÃO ESPECIAL E O ENSINO DE ARTE: MAPEANDO PRODUÇÕES
}

\section{SPECIAL EDUCATION AND THE TEACHING OF ART: MAPPING PRODUCTIONS}

\section{DOI: http://dx.doi.org/10.5965/1984317813032017196}

Patricia Nogueira Aguena, Museu de Arte Contemporânea de Mato Grosso do Sul, Celi Corrêa Neres Universidade Estadual de Mato Grosso do Sul

\begin{abstract}
RESUMO
O presente artigo tem por objetivo levantar literatura e produção de conhecimento sobre o ensino de arte para o aluno cego na escola comum, com base nos últimos treze anos, de 2000 a 2012 a partir de pesquisas envolvendo o ensino de arte nas escolas e a educação especial. Escolheu-se tal recorte de maneira a dar uma visibilidade mais atual sobre o tema e verificar o que a produção pós-década de 1990, marco dos discursos sobre a inclusão da pessoa com deficiência na escola comum diz sobre o objeto em questão. A busca foi realizada a partir dos bancos de teses e dissertações da CAPES (Coordenação de Aperfeiçoamento de Pessoal de Nível Superior), da SCIELO (Scientific Eletronic Library Online), dos anais da CONFAEB (Congresso Nacional de Arte Educadores do Brasil), do banco de trabalhos e pôsteres das reuniões nacionais da ANPED (Associação Nacional de PósGraduação e Pesquisa em Educação), especificamente dos Grupos de Trabalho Educação Especial (GT15) e Educação e Arte (GT24). Verificaram-se os principais objetivos, metodologias e resultados, visando reflexões para subsidiar a prática do professor de arte na escola; concluindo que ainda há escassez significativa de pesquisas sobre o ensino de arte no contexto da educação especial.
\end{abstract}

Palavras-chave: Educação. Arte. Arte-educação. Educação Inclusiva.

\begin{abstract}
This article aims to raise literature and production of knowledge about art education for the blind student in the common school, based on the last thirteen years, from 2000 to 2012 from research involving the teaching of art in schools and education special. Such a clipping was chosen in order to give a more current visibility on the subject and to verify what post-decade-old production of the discourses on the inclusion of people with disabilities in the common school says about the object in question. The search was carried out from the thesis and dissertation banks of the CAPES (Coordinating Improvement of Higher Level Personnel), SCIELO (Scientific Electronic Library Online), the annals of CONFAEB (National Congress of Art Educators of Brazil), the bank Of works and posters of the national meetings of the ANPED (National Association of Graduate Studies and Research in Education), specifically the Working Groups Special Education (GT15) and Education and Art (GT24). The main objectives, methodologies and results were verified, aiming at reflections to subsidize the art teacher's practice in the school; Concluding that there is still a significant shortage of research on art education in the context of special education.
\end{abstract}

Keywords: Education. Art. Art-education. Inclusive education. 


\section{EDUCAÇÃO ESPECIAL E O ENSINO DE ARTE: MAPEANDO PRODUÇÕES}

O presente artigo objetiva levantar literatura e a produção de conhecimento a respeito do ensino de arte para o aluno cego na escola comum, fazendo um recorte dos últimos treze anos, de 2000 a 2012 a partir de teses, artigos e dissertações envolvendo o ensino de arte nas escolas e a educação especial. Escolheu-se tal recorte na tentativa de dar uma visibilidade mais atual sobre o tema e verificar o que a produção pós-década de 1990, marco dos discursos sobre a inclusão da pessoa com deficiência na escola comum e cenário de reformas do Estado brasileiro diz sobre o objeto em questão, segundo (NUNES, 2010; KASSAR, 2011 e GARCIA, 2013).

A busca foi realizada a partir dos bancos de teses e dissertações da CAPES (Coordenação de Aperfeiçoamento de Pessoal de Nível Superior), da SCIELO (Scientific Eletronic Library Online), dos anais do CONFAEB $^{1}$ (Congresso Nacional de Arte Educadores do Brasil), do banco de trabalhos e pôsteres das reuniões nacionais da ANPED (Associação Nacional de Pós-Graduação e Pesquisa em Educação), especificamente dos Grupos de Trabalho Educação Especial (GT15) e Educação e Arte (GT24). Buscou-se verificar os principais objetivos, metodologias e resultados, a fim de gerar reflexões que possam vir a subsidiar a prática do professor de arte na escola.

Se existe um consenso, conforme postula (PADILHA, 2008), entre pesquisadores da educação, é de que as práticas tanto no interior quanto exterior à escola devam lidar com as diferenças. Entretanto, outra questão complexa e preocupante, segundo a autora, seria como esses profissionais estão lidando com essas diferenças no cotidiano. "A incursão de análise em práticas escolares cotidianas é fundamental para percebermos como os alunos com deficiência estão tendo acesso à escola regular e principalmente ao conhecimento por ela veiculado." (GARCIA, 2008, p.19).

(BUENO, 2006) reforça ainda que as pesquisas devem evidenciar os percursos e a situação desses alunos dentro da escola, relacionando a vivência escolar com o meio social, considerando ainda que as condições socioeconômicas e culturais empurram papel decisivo para os processos de escolarização.

\footnotetext{
${ }^{1}$ Congresso promovido pela FAEB (Federação de Arte Educadores do Brasil).
} 
Portanto, o foco principal do presente artigo é o de levantar produções em torno do ensino de arte para o aluno cego na escola comum, tendo como referência as produções de pesquisadores da educação da ANPED, CAPES, SCIELO e FAEB, a fim de investigar esse cotidiano de modo a subsidiar a prática do professor de arte em torno da deficiência visual na escola. Haja vista ser essa disciplina um produto estético ${ }^{2}$ da atividade humana que reflete o contexto e a cultura em que está inserida. Postula (MENDONÇA, 2010) que a riqueza da arte, no que concerne à sua prática, estaria em condensar em si, milênios de aperfeiçoamento atingidos historicamente pelo trabalho humano proporcionando fruição às pessoas que apreciam.

A delimitação do tema pode parecer a princípio um tanto específica, por focar a deficiência visual, no entanto, sobre esse recorte do objeto de estudo proposto, (PADILHA, 2008) destaca que a delimitação de um objeto de estudo não diminui sua relevância social se compreendermos que se trata de aspectos particulares de uma totalidade, entendida como as contradições que interagem e que as investigações não se limitem a meros fatos episódicos, mas que sejam entendidos e analisados em sua relação com a história, a cultura, a sociedade e o poder. (BARRA, 2006) reforça ainda que o desafio dos trabalhos de pesquisa nas universidades seria o de confrontar o real no seu particular para se chegar à totalidade, pois os objetos recortados na sua particularidade e investigados em suas peculiaridades vão ao encontro do mais complexo e à totalidade da realidade. Logo, o presente estudo investiga a prática do ensino de uma das disciplinas que nos faz pensar sobre os novos conteúdos impressos no cotidiano, justamente àqueles que constroem a cultura visual ${ }^{3}$ de maneira conceitual $^{4}$ : os alunos cegos 5 .

\footnotetext{
${ }^{2}$ Estética origina-se do grego aisthésis, que significa percepção. Ramo da filosofia cuja finalidade é o estudo da percepção da natureza do belo ou de sua supressão bem como dos princípios que fundamentam a obra de arte em suas variadas formas, técnicas e concepções.

${ }^{3}$ Cultura Visual passou a ser empregado em nosso país a partir de 1990 para fazer alusão aos meios de comunicação como a televisão e a internet, conforme (BARBOSA, 2009).

${ }^{4}$ Segundo (VYGOTSKY, 1989, p.63) "a palavra vence a cegueira". Ou seja, Vygotsky enfoca a importância da linguagem e da construção dos conceitos favorecidos pelo sistema braile, analisando que mais importante do que o signo é o significado, socialmente construído por meio da mediação caracterizada na figura do professor.

${ }^{5}$ Conforme (BRUNO, 1999) o conceito de deficiência visual relaciona-se a dois grupos diversos: cegueira e baixa visão (congênita ou adquirida), ou visão subnormal, sendo que a primeira se refere à perda total da visão em ambos os olhos ou percepção luminosa e que segundo o Código Internacional das Doenças (CID) considera a acuidade visual inferior a 0.05 ou campo visual inferior a 10 graus, após o melhor tratamento ou correção óptica específica. Ainda segundo a autora, o enfoque educacional estaria na utilização do sistema braile, de recursos didáticos, tecnológicos e equipamentos especiais para o processo de comunicação e leitura-escrita para esses sujeitos.
} 


\subsection{A PRODUÇÃO DA ANPED DE 2000 A 2012}

A busca por trabalhos e pôsteres produzidos nas reuniões anuais da ANPED de 2000 a 2012 encontrou 08 produções relacionando arte e deficiência, como se verifica no quadro a seguir.

Quadro 1: Anais da ANPED de 2000 a 2012

\begin{tabular}{|c|c|c|c|c|}
\hline Pesquisador & Ano & Título & $\begin{array}{l}\text { Deficiência } \\
\text { Pesquisada }\end{array}$ & $\begin{array}{l}\text { Formação do } \\
\text { pesquisador }\end{array}$ \\
\hline $\begin{array}{l}\text { KOHATSU, Lineu } \\
\text { Norio }\end{array}$ & 2000 & $\begin{array}{l}\text { A expressão fotográfica de uma jovem com } \\
\text { síndrome de Down }\end{array}$ & Intelectual & Psicologia \\
\hline $\begin{array}{l}\text { LOPES, Ana } \\
\text { Elisabete }\end{array}$ & 2005 & $\begin{array}{l}\text { Ato fotográfico e processos de inclusão: } \\
\text { análise dos resultados de uma pesquisa- } \\
\text { intervenção }\end{array}$ & Intelectual & Arte \\
\hline $\begin{array}{l}\text { ROSA, Yáskara } \\
\text { Beiler Dalla }\end{array}$ & 2005 & $\begin{array}{l}\text { Interação e inclusão de portadores de } \\
\text { necessidades educacionais especiais }\end{array}$ & Intelectual & Arte \\
\hline $\begin{array}{l}\text { REILY, Lúcia } \\
\text { Helena }\end{array}$ & 2009 & $\begin{array}{l}\text { Nas margens dos manuscritos e da vida: } \\
\text { representações de deficientes em iluminuras } \\
\text { medievais }\end{array}$ & $\begin{array}{l}\text { Física, intelectual, } \\
\text { auditiva e visual }\end{array}$ & Arte \\
\hline $\begin{array}{l}\text { SILVEIRA, Tatiana } \\
\text { dos Santos da }\end{array}$ & 2009 & $\begin{array}{l}\text { Ela fica ali na sala de aula, os alunos fazem, } \\
\text { ela ganha folha pra desenhar: inclusão } \\
\text { escolar de educandos cegos em artes }\end{array}$ & Visual & Arte \\
\hline $\begin{array}{l}\text { ALVES, Jefferson } \\
\text { Fernandes }\end{array}$ & 2011 & $\begin{array}{l}\text { Por um olhar para além da visão: fotografia e } \\
\text { cegueira }\end{array}$ & Visual & Pedagogia \\
\hline $\begin{array}{l}\text { VILARONGA, } \\
\text { Iracema }\end{array}$ & 2011 & $\begin{array}{l}\text { Formação, cinema e áudio-descrição: pode a } \\
\text { sétima arte } \\
\text { influenciar no processo construtivo de } \\
\text { pessoas visualmente } \\
\text { limitadas? }\end{array}$ & Visual & Pedagogia \\
\hline $\begin{array}{l}\text { GOMES, Adriana } \\
\text { Leite Limaverde }\end{array}$ & 2012 & $\begin{array}{l}\text { A coerência textual de alunos com síndrome } \\
\text { de Down: uma análise da produção escrita } \\
\text { através do uso de imagens }\end{array}$ & Intelectual & Pedagogia \\
\hline
\end{tabular}

Fonte: Elaborado pela pesquisadora.

Dessas produções, 07 trabalhos fazem parte do GT 15 (Educação Especial) e 01 do GT 24 (Educação e Arte). As produções levantadas indicam que 04 foram propostas por professores de arte no GT 15, 03 por pedagogos (sendo dois deles no GT 15 e um no GT 24) e 01 por um psicólogo, também no GT 15. Quanto à deficiência pesquisada, especificamente, 
04 abordam a deficiência intelectual e 03 a deficiência visual (sendo cego um dos pesquisadores) e 01 engloba a deficiência física, a mental, a surdez e a cegueira. Da pesquisa com a deficiência visual, 02 foram pesquisados por professores de arte, sendo um em contexto escolar. Quanto à metodologia de pesquisa, a abordagem qualitativa foi a mais abundante nos trabalhos encontrados, evidenciando o uso de observações, notas de campo, documentos, entrevistas, oficinas e narrativas orais. Abaixo seguem as pesquisas que abordam arte e a deficiência visual.

A professora de arte (REILY, 2009), por meio de fontes imagéticas primárias e documentos produzidos durante a Idade Média e salvaguardados em bibliotecas britânicas, investigou as iluminuras medievais que representam as imagens de deficientes (físicos, intelectuais, surdos e cegos) aprofundando a compreensão das concepções constituídas sobre o deficiente pela sociedade medieval na Europa. As centenas de imagens levantadas foram debatidas por publicações de especialistas em arte medieval e revelaram o diálogo entre imagens e tradição oral com a literatura popular, e muitas delas evidenciam ora a função moralizante como os deficientes deveriam ser acolhidos ora como instrumentos do poder de Deus sobre os homens, bem como o lugar da marginalidade do deficiente ao representá-lo na mendicância.

(NERES e CORRÊA, 2008) observam que, na Idade Média, uma nova forma de organização da produção se estabeleceu entre os homens: o feudalismo, caracterizado pela propriedade feudal da terra, em torno da qual se deram as relações de produção, baseadas na agricultura e, posteriormente, no comércio. Tais relações caracterizavam-se pela servidão do trabalhador ao senhor feudal. Os princípios religiosos eram forças dominantes nesse período e a prática do abandono das pessoas com deficiência passou a ser condenada. Ainda segundo as autoras, a propagação de valores caritativos e os princípios religiosos dominantes naquele contexto contribuíram para mudanças nas atitudes dos homens, passando a considerar os deficientes como filhos de Deus. "As pessoas com deficiência passaram a ser acolhidas em igrejas, onde foram organizados orfanatos, abrigos para atendê-las com as crianças desamparadas. Ainda nessa concepção, a deficiência também poderia ser vista como resposta aos comportamentos imorais dos homens" (NERES e CORRÊA, 2008, p.152). 
(REILY, 2009) observa em sua pesquisa que muitos deficientes aparecem nos textos como mendigos, recebendo esmolas ou trazendo consigo tigelas na tentativa de receber algum benefício. Infere-se a relevância do estudo de Reily, que demonstra pela imagem a dimensão da condição econômica da deficiência na Idade Média, ressaltando que a miséria está nitidamente marcada na figura do deficiente, numa complexa relação econômica.

No trabalho da professora de arte (SILVEIRA, 2009), o único encontrado relacionando o trabalho com arte para o aluno cego em contexto escolar, a pesquisadora analisou a concepção de escola inclusiva e a prática pedagógica em artes visuais de duas professoras de arte com dois alunos cegos em escolas municipais de Santa Catarina. A pesquisa de abordagem qualitativa utilizou como instrumentos para coleta de dados: entrevistas semiestruturadas, observações das aulas de arte e notas de campo descritivas.

O trabalho revelou, durante as observações realizadas pela pesquisadora, que a inclusão é um desafio a ser superado nas aulas de arte, e apresentou que a falta de formação está presente no discurso dos professores de arte ao que se refere à justificativa para as dificuldades no trabalho com a inclusão. As observações revelaram pouca participação dos alunos cegos nas aulas de arte e que, quando participavam, contavam com o auxílio dos colegas. Existia pouca preocupação docente com o planejamento, ausência de materiais adaptados, presença de atividades aleatórias e sem relação com o restante do grupo, pouca articulação entre as professoras de arte com o serviço de atendimento educacional especializado, pouca discussão sobre a cegueira no espaço escolar e que ao aluno cego ficaram mais creditadas as suas dificuldades que suas possibilidades.

O trabalho do pedagogo (ALVES, 2011) realizado a partir dos estudos e da produção de Evgen Bavcar, consagrado fotógrafo cego natural da Eslovênia, problematizou a relação existente entre a fotografia e a cegueira ao elaborar uma oficina de fotografia básica realizada no Instituto de Educação e Reabilitação de Cegos em Natal no Rio Grande do Norte, com 09 participantes cegos, utilizando procedimentos criativos inspirados em Bavcar de caráter háptico ${ }^{6}$-verbal. (ALVES, 2011) demonstrou que a concepção do olhar, por meio de procedimentos multissensoriais, transgrediu os limites da mera percepção visual e que esses

\footnotetext{
${ }^{6}$ Relativo ao tato, sensível ao tato.
} 
mesmos procedimentos utilizados pelos cegos no ato fotográfico apresentaram a grande capacidade de significação dessas pessoas.

O trabalho da pedagoga (VILARONGA, 2011) teve como objetivo demonstrar as contribuições da arte cinematográfica tendo a audiodescrição ${ }^{7}$ como ferramenta de acessibilidade. Quanto ao procedimento metodológico, foi adotada a história oral de três colaboradores cegos da cidade de Salvador/Bahia e a vivência da própria pesquisadora que também é cega. (VILARONGA, 2011) conclui que a importância da família e dos professores, desde a infância, ao descrever o mundo e suas representações, é fundamental para a construção de imagens mentais como processo facilitador para quem não enxerga. Portanto, a palavra (audiodescrição) é a ferramenta de acesso ao mundo das significações.

\subsection{BANCO DE TESES E DISSERTAÇÕES DA CAPES}

O levantamento no banco de teses e dissertações da CAPES de 2009 a 2012, tendo como palavras-chave "arte, arte-educação, educação inclusiva, educação especial, inclusão", revelou um total de 09 produções que relacionam arte e deficiência.

O levantamento realizado demonstrou que, entre as 09 produções encontradas, 04 foram propostas por professores de arte, 03 por pedagogos, 01 por um comunicólogo social e 01 por profissional com formação em letras. Quanto à deficiência pesquisada, especificamente, 04 abordam a deficiência visual, 04 a deficiência intelectual e 01 contempla todas as deficiências. O levantamento ainda demonstrou que 04 produções foram realizadas em escola especial, apenas 01 em escola comum, 03 em museus e 01 considerou os três contextos supracitados. Ao todo são 8 dissertações de mestrado e 01 tese de doutorado. Quanto à metodologia de pesquisa, a abordagem qualitativa e a pesquisa-ação foram as mais abundantes nos trabalhos encontrados, evidenciando o uso de observações, entrevistas, narrativas orais, registros fotográficos e estudos de caso. O quadro, a seguir, apresenta as pesquisas encontradas.

\footnotetext{
${ }^{7}$ Recurso de acessibilidade para a inclusão cultural das pessoas com deficiência visual em espetáculos, cinema, teatro e museus que consiste na descrição clara e objetiva de todas as informações visuais. Exemplo: Expressões faciais e corporais que comuniquem algo, informações sobre o ambiente, figurinos, efeitos especiais, mudanças de tempo e espaço, além da leitura de créditos, títulos e qualquer informação escrita na tela. No corpo desta dissertação aparece a palavra audiodescrição em conformidade às novas regras gramaticais da língua portuguesa. A grafia áudio-descrição permanece em respeito ao título de pesquisas desenvolvidas.
} 
Quadro 2: Banco de Teses e Dissertações da CAPES de 2000 a 2012

\begin{tabular}{|c|c|c|c|c|c|}
\hline Pesquisador & Ano & Título & $\begin{array}{l}\text { Deficiência } \\
\text { Pesquisada }\end{array}$ & $\begin{array}{l}\text { Formaçãodo } \\
\text { pesquisador }\end{array}$ & $\begin{array}{l}\text { Instituição(s) em que foram } \\
\text { desenvolvidas as pesquisas }\end{array}$ \\
\hline $\begin{array}{l}\text { SIMÓ, Cristiane } \\
\text { Higueras }\end{array}$ & 2010 & $\begin{array}{c}\text { O estado da arte nas } \\
\text { teses acadêmicas que } \\
\text { abordam arte e } \\
\text { inclusão: Um recorte } \\
\text { de } 1998 \text { a } 2008 \text { no } \\
\text { Brasil }\end{array}$ & Todas & Arte & $\begin{array}{l}\text { UDESC - Universidade do Estado } \\
\text { de Santa Catarina } \\
\text { (Florianópolis) }\end{array}$ \\
\hline $\begin{array}{l}\text { ANASTASIOU, } \\
\text { Helene Paraskevi }\end{array}$ & 2012 & $\begin{array}{c}\text { Ensino e } \\
\text { aprendizagem em } \\
\text { artes visuais: Adultos } \\
\text { com síndrome de } \\
\text { Down em interação }\end{array}$ & Intelectual & Arte & $\begin{array}{c}\text { Ong Amigo Down/São José (SC); } \\
\text { UDESC }\end{array}$ \\
\hline $\begin{array}{l}\text { BERNARDO, } \\
\text { Sergio Figueiredo }\end{array}$ & 2012 & $\begin{array}{c}\text { A música na educação } \\
\text { de pessoas com } \\
\text { deficiência visual: } \\
\text { Uma experiência na } \\
\text { Unidade Educacional } \\
\text { Especializada José } \\
\text { Álvares de Azevedo }\end{array}$ & Visual & Pedagogia & $\begin{array}{c}\text { Unidade Educacional Especializada } \\
\text { José Álvares de Azevedo/Belém } \\
\text { (PA); UFPA - Universidade } \\
\text { Federal do Pará }\end{array}$ \\
\hline $\begin{array}{l}\text { FERREIRA, } \\
\text { Anelise Barra }^{8}\end{array}$ & 2012 & $\begin{array}{l}\text { Aluno faz foto? O } \\
\text { fotografar na escola } \\
\text { (especial) }\end{array}$ & Intelectual & Pedagogia & $\begin{array}{c}\text { Escola Municipal Especial de } \\
\text { Ensino Fundamental Prof. Elyseu } \\
\text { Paglioli/Porto Alegre (RS); UFRS- } \\
\text { Universidade Federal do Rio } \\
\text { Grande do Sul }\end{array}$ \\
\hline $\begin{array}{l}\text { GARCIA, Roseli } \\
\text { Behaker }\end{array}$ & 2012 & $\begin{array}{l}\text { A percepção de } \\
\text { esculturas por três } \\
\text { pessoas cegas }\end{array}$ & Visual & Letras & $\begin{array}{l}\text { Pinacoteca/SP; Mackenzie - } \\
\text { Universidade Presbiteriana/SP }\end{array}$ \\
\hline $\begin{array}{l}\text { MARCHEZI, } \\
\text { Fabiana }\end{array}$ & 2012 & $\begin{array}{l}\text { Acessibilidade em } \\
\text { museus de arte: } \\
\text { Questões para } \\
\text { elaboração de áudio- } \\
\quad \text { guias }\end{array}$ & Visual & Pedagogia & $\begin{array}{c}\text { MAM - Museu de Arte Moderna } \\
\text { de São Paulo; MoMa - The } \\
\text { Museum of Modern Art de Nova } \\
\text { Iorque; The Metropolitan Museum } \\
\text { of Art de Nova Iorque; Pinacoteca } \\
\text { do Estado de São Paulo; } \\
\text { Mackenzie -Universidade } \\
\text { Presbiteriana/SP }\end{array}$ \\
\hline $\begin{array}{l}\text { MATTOSO, } \\
\text { Verônica de } \\
\text { Andrade }\end{array}$ & 2012 & $\begin{array}{l}\text { Ora, direis, ouvir } \\
\text { imagens? Um olhar } \\
\text { sobre o potencial } \\
\text { informativo da áudio- } \\
\text { descrição aplicada a } \\
\text { obras de artes visuais } \\
\text { bidimensionais como } \\
\text { representação sonora } \\
\text { da informação em arte } \\
\text { para pessoas com }\end{array}$ & Visual & $\begin{array}{l}\text { Comunicaçã } \\
\text { o Social }\end{array}$ & $\begin{array}{c}\text { Galeria de Arte Universo/Niterói } \\
\text { (RJ); UFRJ - Universidade Federal } \\
\text { do Rio de Janeiro }\end{array}$ \\
\hline
\end{tabular}

\footnotetext{
${ }^{8}$ Única tese de doutorado encontrada cujo conteúdo está disponível na íntegra.
} 


\begin{tabular}{|c|c|c|c|c|c|}
\hline & & deficiência & & & \\
\hline $\begin{array}{c}\text { OLIVEIRA, Uillian } \\
\text { Trindade }^{9}\end{array}$ & 2012 & $\begin{array}{l}\text { A importância da arte } \\
\text { na inclusão escolar e } \\
\text { no desenvolvimento } \\
\text { de pessoas com } \\
\text { necessidades } \\
\text { educativas especiais }\end{array}$ & Intelectual & Arte & $\begin{array}{l}\text { Escola Municipal de Educação } \\
\text { Fundamental do Município de } \\
\text { Cariacica/ES; UFES - } \\
\text { Universidade Federal do Espírito } \\
\text { Santo }\end{array}$ \\
\hline $\begin{array}{l}\text { VERAS, Carlos } \\
\text { Alberto Araújo }\end{array}$ & 2012 & $\begin{array}{l}\text { A arte Down: A } \\
\text { educação especial e a } \\
\text { cultura amazônica }\end{array}$ & Intelectual & Arte & $\begin{array}{c}\text { CIEES - Centro Integrado de } \\
\text { Educação Especial/Belém (PA); } \\
\text { UNAMA - Universidade da } \\
\text { Amazônia }\end{array}$ \\
\hline
\end{tabular}

Fonte: Elaborado pela pesquisadora.

A dissertação de mestrado de (SIMÓ, 2010) objetivou realizar um mapeamento das teses de doutorado que dialogam com o ensino de arte e a educação inclusiva (política a ser alcançada no Brasil) e/ou a educação especial (conforme aparece na maioria das teses). (SIMÓ, 2010) traça um estado da arte dos trabalhos acadêmicos revelando o que as teses de doutorado relatam sobre a temática, tendo como recorte os anos de 1998 a 2008.

A professora de arte utilizou como metodologia para a sua pesquisa o estudo qualitativo no qual a coleta de dados se desenvolveu pela análise documental, ou seja, identificação e observação das teses. A pesquisadora utilizou, como instrumento de busca, os bancos de dados da CAPES e de bibliotecas virtuais como Domínio Público, SibiNet (Rede de Serviço Sibi/USP), o IBICT (Instituto Brasileiro de Informação em Ciência e Tecnologia), o banco de informações da Biblioteca Virtual da USP e o INEP (Instituto Nacional de Estudos e Pesquisas Educacionais Anísio Teixeira) com variações de palavras-chave relacionando tema e título. A pesquisa encontrou cerca de sete teses de doutorado que foram produzidas em diferentes áreas do conhecimento que articulam o ensino de arte e a educação inclusiva e/ou a educação especial com referenciais teóricos diversos.

(SIMÓ, 2010) constatou, entre as teses mapeadas, focos distintos sobre a abordagem do ensino de arte. Verificou também que algumas valorizavam a arte como linguagem, outras como área de conhecimento com conteúdos próprios e ainda observou que, em algumas, a arte se configurava como facilitadora para a educação inclusiva. A pesquisadora então organizou sua dissertação em categorias que foram divididas em capítulos independentes conforme o

\footnotetext{
${ }^{9}$ Única dissertação que tem a escola comum como contexto.
} 
que cada tese revelou, como: educação e inclusão (termo utilizado pela autora), formação de professores (formação do professor de arte e de Educação Especial), a relação da arte com a construção do conhecimento humano e o ensino de arte para as pessoas com necessidades educacionais especiais (termo utilizado pela autora).

(SIMÓ, 2010) constatou a escassez de teses de doutorado que relacionam a temática proposta pela dissertação, a necessidade de recursos no atendimento às especificidades dos estudantes com deficiência na escola comum, divergência quanto ao emprego entre termos utilizados para designar as pessoas com deficiência, necessidade de qualificação docente para a concretude da educação inclusiva. O levantamento feito por (SIMÓ, 2010) aponta, ainda, uma concentração maior de teses relacionando o objeto de estudo à área da psicologia, com destaque para o desenvolvimento humano, tendo as escolas especializadas como contexto e sendo a deficiência intelectual a mais abordada. A pesquisadora apresenta apenas duas teses de doutorado que relacionam arte e cegueira. A primeira, defendida em 2001, pelo psicólogo Francisco José de Lima, com o título "O efeito do treino com desenhos em relevo no reconhecimento háptico de figuras bidimensionais tangíveis". A segunda, defendida em 2007, pela professora de arte Amanda Pinto da Fonseca Tojal, intitulada "Políticas públicas culturais de inclusão de públicos especiais em museus”. Segundo (SIMÓ, 2010), a tese dessa pesquisadora tem como diretriz principal as possibilidades de conceber o museu como instrumento para políticas públicas culturais de inclusão voltadas às pessoas com deficiências sensoriais, físicas e mentais, bem como programas de acessibilidade e ação educativa inclusiva em museus. (TOJAL, 2007) apresenta adaptações pedagógicas na produção e leitura de objetos culturais e análise quanto à acessibilidade física e sensorial de museus nacionais e internacionais, por meio de bases metodológicas de caráter pluralista interdisciplinar. A tese de doutorado de (LIMA, 2001) objetivou investigar o efeito do treino com desenhos em relevo no reconhecimento háptico de figuras bidimensionais tangíveis por alunos cegos, alfabetizados pelo sistema Braille, tendo a escola pública como contexto. (LIMA, 2001) evidencia a importância da prática em leitura de imagens por meio de materiais em relevo como forma de inclusão do aluno cego em áreas do conhecimento que utilizam desenhos, mapas, por exemplo.

O objetivo da dissertação de mestrado do pedagogo (BERNARDO, 2012) foi o de compreender a dinâmica da educação musical na Unidade Educacional Especializada José 
Álvares de Azevedo, em Belém do Pará, com o atendimento Educacional Especializado para professores e aluno cegos na perspectiva da educação inclusiva. Para a consecução do objetivo, a pesquisa utilizou como metodologia a abordagem qualitativa em torno de um estudo de caso. Como técnica, foi empregada a documentação indireta por meio da pesquisa bibliográfica e pesquisa documental, bem como a observação e entrevista semiestruturada.

(BERNARDO, 2012) verificou que a unidade educacional possui várias frentes de ação, tais como: o atendimento de alunos com deficiência visual, formação de educadores da Rede Estadual de Ensino, e a organização de Jornadas Pedagógicas envolvendo arte e sociedade. A pesquisa constatou que existe um terreno fértil de possibilidades para a produção de conhecimento dos processos criativos dos alunos com deficiência visual por meio da música e que a unidade educacional vem tentando adequar-se ao processo de normalização do atendimento educacional especializado.

A pesquisadora, com formação em letras (GARCIA, 2012) objetivou, em sua dissertação, ampliar o conhecimento sobre a percepção da obra de arte pela pessoa cega, especialmente a percepção de esculturas. A dissertação foi realizada com três pessoas cegas congênitas, na Pinacoteca do Estado de São Paulo, sendo os dados coletados por meio de entrevistas e depoimentos escritos, enquanto os sujeitos envolvidos realizavam a exploração tátil de duas esculturas figurativas. Garcia evidenciou convergência e concordância entre os três sujeitos, tanto na exploração da escultura, como no depoimento escrito, quanto aos elementos percebidos das esculturas, evidenciando identificação denotativa referente aos objetos artísticos.

A pedagoga (MARCHEZI, 2012) em sua dissertação de mestrado analisou os áudioguias utilizados em museus de arte como ferramenta de acessibilidade para públicos cegos ou com baixa visão. A pesquisadora analisou os discursos verbais veiculados pelos áudio-guias (descrição) e os elementos sonoros presentes (trilhas sonoras). Os materiais foram coletados do Museu de Arte Moderna de São Paulo (MAM), do The Museum of Modern Art - New York (MoMA), do The Metropolitan Museum of Art (The Met) e da Pinacoteca do Estado de São Paulo.

A comunicóloga (MATTOSO, 2012), em sua dissertação, pesquisou o potencial da audiodescrição aplicada a obras de artes visuais bidimensionais como representação sonora da 
Informação em Arte para pessoas com deficiência visual. A pesquisa-ação e o modelo estrutural para pesquisas em artes plásticas, tendo como aporte as diretrizes da audiodescrição em museus, foram as metodologias utilizadas pela pesquisadora. (MATTOSO, 2012) investiga os aspectos intrínsecos e extrínsecos da audiodescrição, considerando a acessibilidade física, metodológica, instrumental, comunicacional, programática e atitudinal das obras de arte. Utiliza como referencial teórico o fluxo informacional da audiodescrição, a partir da Ciência da Informação e a estrutura da primeira exposição de obras de artes visuais bidimensionais com audiodescrição no Estado do Rio de Janeiro. (MATTOSO, 2012) não apenas confirma o potencial informativo que existe no acesso das pessoas cegas a obras de arte bidimensionais, como ainda estrutura um documentário formado por elementos que compuseram a exposição mencionada como forma futura de criação da primeira base ${ }^{10}$ de dados brasileira de acesso livre a audiodescrições de obras de artes visuais bidimensionais.

\subsection{PERIÓDICOS DA SCIELO DE 2000 A 2012}

O levantamento na biblioteca eletrônica da SCIELO de 2000 a 2012, tendo como palavras-chave "arte, arte-educação, educação inclusiva, educação especial, inclusão", encontrou um total de 03 produções que relacionam arte e deficiência. O levantamento realizado demonstrou que entre as 03 produções encontradas, 02 foram propostas por uma mesma professora de arte e 01 por duas fonoaudiólogas. Quanto à deficiência pesquisada, especificamente, 01 aborda a deficiência auditiva, 01 a deficiência visual e outra o contexto da inclusão nas escolas. O levantamento apontou que 01 produção foi realizada em clínicas e hospitais e apenas 01 considerou o ensino de arte na escola comum. Quanto à metodologia de pesquisa, a abordagem qualitativa, evidenciando o uso de observações, notas, diários de campo e estudos de caso e análise documental foram as metodologias desenvolvidas nas produções conforme quadro a seguir.

Quadro 3: SCIELO de 2000 a 2012

\begin{tabular}{|c|c|c|c|c|c|}
\hline Pesquisador & Ano & Título & $\begin{array}{l}\text { Deficiência } \\
\text { Pesquisada }\end{array}$ & $\begin{array}{c}\text { Formação do } \\
\text { pesquisador }\end{array}$ & Revista Publicada \\
\hline
\end{tabular}

\footnotetext{
${ }^{10}$ Ainda não disponível na internet.
} 


\begin{tabular}{|c|c|c|c|c|c|}
\hline $\begin{array}{l}\text { BOSCOLO, } \\
\text { Cibele Cristina; } \\
\text { PINOTTI, Kele } \\
\text { Jaqueline }\end{array}$ & 2008 & $\begin{array}{l}\text { A dramatização como estratégia } \\
\text { de aprendizagem da linguagem } \\
\text { escrita para o deficiente auditivo }\end{array}$ & Auditiva & Fonoaudiologia & $\begin{array}{l}\text { Revista Brasileira de } \\
\text { Educação Especial, } \\
\text { vol. } 14, \mathrm{n}^{\circ} 1- \\
\text { Marília Jan/Abr.2008 }\end{array}$ \\
\hline $\begin{array}{l}\text { REILY, Lúcia } \\
\text { Helena }\end{array}$ & 2008 & $\begin{array}{l}\text { Músicos cegos ou cegos } \\
\text { músicos: representações de } \\
\text { compensação sensorial na } \\
\text { História da Arte }\end{array}$ & Visual & Arte & $\begin{array}{c}\text { Caderno CEDES, } \\
\text { vol. } 28, \mathrm{n}^{\circ} 75- \\
\text { Campinas } \\
\text { Mai/Ago. } 2008\end{array}$ \\
\hline $\begin{array}{l}\text { REILY, Lúcia } \\
\text { Helena }\end{array}$ & 2010 & $\begin{array}{l}\text { O ensino de artes visuais na } \\
\text { escola no contexto da inclusão }\end{array}$ & Inclusão & Arte & $\begin{array}{c}\text { Caderno CEDES, } \\
\text { vol. } 30, \mathrm{n}^{\circ} 80- \\
\text { Campinas } \\
\text { Jan/Abr.2010 }\end{array}$ \\
\hline
\end{tabular}

Fonte: Elaborado pela pesquisadora.

A professora de arte (REILY, 2008) objetivou descrever as concepções das representações do músico cego por meio de obras da História da Arte. Salienta que esse tipo de representação envolvendo músicos e cegueira era recorrente na Antiguidade, na Idade Média e no Barroco, permitindo demonstrar o papel do músico cego na sociedade. (REILY, 2008, p.252 e 253) reforça que:

\begin{abstract}
No decorrer da história da arte, vemos a cegueira representada figurativamente por meio dos seguintes elementos: Olhos fechados/abertos após a cura; olhos esbranquiçados, órbita vazia, olhos feridos ou disformes, olhos de vidro, direção do olhar assimétrico, olhar ausente, vazio; uso de vendas, de óculos escuros, de lentes grossas, de recursos ópticos; indicação pelo apontar, mostrando ou tocando os olhos; pistas posturais, como a cabeça erguida, braços estendidos diante do corpo, mão aberta varrendo o ar, passo inseguro, com um pé à frente, mapeando o terreno a procura de obstáculos ou buracos; corpo prostrado, figura deitada na cama, figura sentada desocupada ao lado de outra pessoa trabalhando a seu lado; presença de bengala, vara ou instrumento musical; tamanho das mãos proporcionalmente aumentadas; mãos tocando, sentindo algo; presença de auxiliar, guia, criança ou cachorro levando o cego; presença de tigela ou chapéu para o público colocar moedas.
\end{abstract}

(REILY ,2008), ao analisar o conjunto de obras presente no artigo em questão, evidencia pouquíssimos exemplos de deficientes como sendo capazes de fazer parte do mundo do trabalho. (NERES, 1999) demonstra que atualmente os postos de trabalho ocupados pela pessoa cega são àqueles em que a visão é algo dispensável, como o de técnico de Câmara Escura em hospitais e a própria instituição especializada. (REILY, 2008) destaca que na Idade Média predominava a figura do cego músico atrelado à marginalidade, à miséria, 
à mendicância, ao assistencialismo, ao mito da superação e da compensação pela audição, conforme postula (REILY, 2008, p.259):

Os temas miséria e mendicância são constantes nos retratos dos cegos músicos [...]. Rembrandt van Rijn, Pablo Picasso, Georges de La Tour e vários outros utilizam a coloração sombria, a composição de figura em primeiro plano, com a postura de ombros caídos, a expressão triste do rosto, para falar da condição precária desta figura urbana, cujo trabalho é ao mesmo tempo ganha-pão e manifestação de súplica.

A pesquisadora conclui "[...] que as concepções de dependência, incapacidade e supercompensação pela perda da visão ainda permeiam as representações sociais da deficiência visual [...]" (REILY, 2008, p.264). A professora de arte finaliza, destacando entre as representações estudadas do cego músico, que as condições de vida precárias impossibilitam as crianças cegas ao acesso tanto à educação de maneira geral como à educação musical, tendo a mendicância e o assistencialismo lado a lado. (NERES e CORRÊA, 2008, p.163) destaca ainda que:

[...] a pessoa com deficiência visual enfrenta de forma mais acentuada as dificuldades para sua inserção no mercado de trabalho, haja vista que não tem as mesmas oportunidades que os outros indivíduos têm em relação à sua formação intelectual e profissional, não preenchem os padrões de "beleza" comumente aceitos e valorizados, reforçando a descrença em relação à sua capacidade.

Em outro artigo, a professora de arte (REILY, 2010) visou problematizar o ensino de arte para alunos com deficiência, com base na produção científica de conhecimento do país a partir de contextos educacionais e culturais. (REILY, 2010) apresenta a diversidade que se acentuou nas escolas brasileiras atualmente a partir do contexto inclusivo, que assegura aos estudantes com deficiência espaço na escola comum. A pesquisadora destaca a morosidade da maioria dos cursos de licenciatura em arte em adequar as grades curriculares para o contexto da educação especial de forma a preparar o professor para atuar nas escolas frente a esse contexto. A pesquisadora afirma que muitos trabalhos que envolvem arte e que são 
desenvolvidos no contexto institucional assumem um caráter terapêutico, segundo (REILY, 2010, p.90):

O desenho e a pintura são utilizados como técnicas expressivas, como instrumentos diagnósticos, como meios de desenvolvimento de coordenação manual, voltados para trabalhar a autoestima e a socialização. Muitas vezes, a arte trabalha como um braço da terapia ocupacional ou da pedagogia, dando suporte ao treinamento em artesanato ou no desenvolvimento gráfico, tendo em vista a escrita na sua dimensão motora, como vemos em Castro (2001). Não pretendemos, com isso, criticar tais pesquisas, que, certamente, poderão subsidiar questões técnicas, inclusive para o trabalho do professor de arte. Entretanto, é preciso incentivar a produção de conhecimento que traga suporte para o professor de arte que atua com um alunado altamente heterogêneo, de modo a servir de apoio para a escola no seu processo de aprendizagem, sem o viés clínico.

A professora de arte salienta a ausência de socialização e publicação no campo da arte, o que prejudica essa área de conhecimento, bem como evidencia o trabalho com arte em contextos clínicos reforçando que não é, simplesmente, transpor os saberes constituídos num espaço institucional para outro espaço de inclusão. (REILY, 2010) conclui a importância da produção de conhecimento dada à seriedade com que muitos trabalhos são realizados de maneira que possa vir a subsidiar o ensino de arte na escola.

\subsection{CONFAEB}

O levantamento das produções nos anais do CONFAEB (Congresso Nacional de Arte Educadores do Brasil, disponíveis pela FAEB (Federação de Arte Educadores do Brasil), contemplam os anos de 2006 a 2012. Tendo como palavras-chave "arte, arte-educação, educação inclusiva, educação especial, inclusão, cegueira, escola comum" foi encontrado um total de 22 produções que relacionam arte e deficiência.

Quadro 4: CONFAEB 2006, 2007, 2008, 2010, 2011 e 2012

\begin{tabular}{|c|c|c|c|c|}
\hline Pesquisador & Ano & Título & $\begin{array}{c}\text { Deficiência } \\
\text { Pesquisada }\end{array}$ & $\begin{array}{c}\text { Formação do } \\
\text { pesquisador }\end{array}$ \\
\hline
\end{tabular}




\begin{tabular}{|c|c|c|c|c|}
\hline $\begin{array}{l}\text { AMARAL, Maria das Vitórias } \\
\text { Negreiras do; FREITAS, } \\
\text { Alessandra Menezes Machado de }\end{array}$ & 2007 & $\begin{array}{l}\text { Educação e artes aliadas para } \\
\text { inclusão de educandos surdos }\end{array}$ & Auditiva & Pedagogia \\
\hline ARAÚJO, Haroldo de & 2007 & $\begin{array}{l}\text { Experiência com deficientes } \\
\text { visuais, em projeto de pesquisa e } \\
\text { extensão: Despertou a paixão pela } \\
\text { busca de um ensino de artes } \\
\text { acessível a todos }\end{array}$ & Visual & Arte \\
\hline COSTA, Robson Xavier da & 2008 & $\begin{array}{c}\text { Ensino de arte e educação } \\
\text { inclusiva }\end{array}$ & Inclusão & Arte \\
\hline FERNANDES, Vera Lúcia Penzo & 2008 & $\begin{array}{c}\text { Criatividade e educação inclusiva } \\
\text { no ensino de artes visuais }\end{array}$ & $\begin{array}{l}\text { Educação } \\
\text { Inclusiva }\end{array}$ & Arte \\
\hline $\begin{array}{l}\text { QUEIROZ, Anna Karenina Gomes } \\
\text { de }\end{array}$ & 2008 & $\begin{array}{l}\text { Arte como ferramenta de inclusão } \\
\text { social e educacional }\end{array}$ & Intelectual & Arte \\
\hline $\begin{array}{c}\text { BATISTA, Marina Fenício Soares; } \\
\text { RIZZI, Maria Christina de Souza } \\
\text { Lima }\end{array}$ & 2010 & $\begin{array}{l}\text { Museu da imagem e do som: } \\
\text { iniciativas de inclusão }\end{array}$ & Acessibilidade & $\begin{array}{l}\text { Arte e Terapia } \\
\text { Ocupacional }\end{array}$ \\
\hline $\begin{array}{c}\text { CIRILLO, Aparecido José; } \\
\text { COSTA, Rosa da Penha Ferreira } \\
\text { da; RODRIGUES, Maria Regina }\end{array}$ & 2010 & $\begin{array}{l}\text { A cidade e seus fluxos: artes e } \\
\text { cultura na educação especial }\end{array}$ & Inclusão & Arte \\
\hline $\begin{array}{l}\text { LIMA, Marlini Dorneles de; } \\
\text { ROCHA, Deizi Domingues da }\end{array}$ & 2010 & $\begin{array}{c}\text { Dançando a corporeidade da } \\
\text { pessoa com deficiência visual: } \\
\text { Um relato de experiência a partir } \\
\text { da pesquisa ação }\end{array}$ & Visual & Educação Física \\
\hline $\begin{array}{l}\text { LIMA, Marlini Dorneles de; } \\
\text { TERRA, Alessandra Matos; } \\
\text { TONIETTI, Diego Ferreira }\end{array}$ & 2010 & $\begin{array}{l}\text { Trabalhando com a dança na } \\
\text { escola na perspectiva da inclusão }\end{array}$ & Inclusão & Educação Física \\
\hline PUCCETTI, Roberta & 2010 & $\begin{array}{l}\text { Arte, educação e inclusão, por um } \\
\text { olhar diferente }\end{array}$ & Inclusão & Arte \\
\hline RABELLO, Roberto Sanches & 2010 & $\begin{array}{c}\text { Ensino de arte e educação } \\
\text { inclusiva: atendimento ao aluno } \\
\text { com deficiência visual em escolas } \\
\text { públicas de Salvador }\end{array}$ & Visual & Artes Cênicas \\
\hline $\begin{array}{l}\text { SILVA, Andreza da Nóbrega } \\
\text { Arruda }\end{array}$ & 2010 & $\begin{array}{l}\text { Áudio-descrição: Tecnologia } \\
\text { assistiva e educacional no teatro }\end{array}$ & Visual & Arte \\
\hline $\begin{array}{l}\text { VALE, Cassia do; REY, Ketheley } \\
\text { Leite Freire }\end{array}$ & 2010 & $\begin{array}{l}\text { Projeto dia: Diversidade, inclusão } \\
\text { e arte um caminho possível em } \\
\text { educação inclusiva }\end{array}$ & $\begin{array}{l}\text { Educação } \\
\text { Inclusiva }\end{array}$ & $\begin{array}{l}\text { Arte, Letras e } \\
\text { Pedagogia }\end{array}$ \\
\hline ALMEIDA, Marilene Oliveira & 2011 & $\begin{array}{c}\text { Contribuições da perspectiva } \\
\text { educacional de Helena Antipoff } \\
\text { para o ensino de arte em Minas } \\
\text { Gerais: Fazenda do Rosário (1940 } \\
\text { - 1970) }\end{array}$ & Escola Nova & Normal Superior \\
\hline KIRST, Adriane Cristine; SILVA, & 2011 & Educação Inclusiva e Arte: A & Inclusão & Arte \\
\hline
\end{tabular}




\begin{tabular}{|c|c|c|c|c|}
\hline Maria Cristina da Rosa Fonseca da & & construção de uma trajetória & & \\
\hline $\begin{array}{c}\text { MENEZES, Flávia Andresa } \\
\text { Oliveira de; SILVA, Josiane de } \\
\text { Jesus da }\end{array}$ & 2011 & $\begin{array}{l}\text { Arte na Educação Especial: } \\
\text { Experiências e Possibilidades }\end{array}$ & $\begin{array}{l}\text { Educação } \\
\text { Inclusiva }\end{array}$ & Arte \\
\hline FREITAS, Ana Cláudia de Oliveira & 2012 & $\begin{array}{c}\text { Tocar para ver: Relato de } \\
\text { experiência - Artes Visuais, com } \\
\text { foco na pessoa com deficiência } \\
\text { visual }\end{array}$ & Visual & Arte \\
\hline $\begin{array}{c}\text { GOMES, Elida Strazzi Moreira; } \\
\text { ISHII, Bianca Iatalesi; MORAES, } \\
\text { João Lúcio de; OLIVEIRA, Patrícia } \\
\text { da Costa Borges; TOMASULO, } \\
\text { Adriana Iniesta }\end{array}$ & 2012 & $\begin{array}{l}\text { O coral cênico da APAE de Mogi } \\
\text { das Cruzes: } \\
\text { O fazer artístico como elemento } \\
\text { de inclusão social }\end{array}$ & Inclusão & $\begin{array}{l}\text { Psicologia, } \\
\text { Fisioterapia, } \\
\text { Comunicação } \\
\text { Social e } \\
\text { Fonoaudiologia }\end{array}$ \\
\hline MOTA, Marina Alves & 2012 & $\begin{array}{c}\text { O ensino da dança para o } \\
\text { deficiente visual }\end{array}$ & Visual & Educação Física \\
\hline NÓBREGA, Andreza & 2012 & $\begin{array}{l}\text { Mediação inclusiva: A áudio- } \\
\text { descrição abre as cortinas do } \\
\text { teatro para pessoa com } \\
\text { deficiência visual. }\end{array}$ & Visual & Arte \\
\hline OLEQUES, Liane Carvalho & 2012 & $\begin{array}{c}\text { Ensino da Arte: Ensinando } \\
\text { desenho a crianças com } \\
\text { deficiência Intelectual }\end{array}$ & Intelectual & Arte \\
\hline PUCCETTI, Roberta & 2012 & $\begin{array}{l}\text { Perfil e formação do professor de } \\
\text { arte de Londrina: O desafio da } \\
\text { educação inclusiva }\end{array}$ & Inclusão & Arte \\
\hline
\end{tabular}

O levantamento realizado demonstrou que, entre as 22 produções encontradas, 14 foram propostas por professores de arte; 03 por professores de educação física; 02 por pedagogos; 01 por um professor de arte em parceria com um terapeuta ocupacional; 01 por um professor de arte em parceria com um pedagogo e um professor de letras, e 01 por um psicólogo em parceria com um fisioterapeuta, um comunicólogo e um fonoaudiólogo. Quanto à deficiência pesquisada, 07 abordam a deficiência visual, 02 a deficiência intelectual, 01 a deficiência auditiva, 07 abordam a inclusão, 03 a educação inclusiva, 01 a acessibilidade e outra a Escola Nova. O levantamento apontou que 10 produções tiveram como contexto a escola, sendo as demais desenvolvidas em museus, instituições especializadas e universidades. Quanto à metodologia de pesquisa, a abordagem qualitativa foi a mais abundante nos trabalhos encontrados, evidenciando o uso de observações e estudos de caso. A seguir são relatadas as pesquisas encontradas que abordam o ensino de arte e o aluno cego. 
O professor de arte (ARAÚJO, 2007) investigou a produção dos esquemas gráficos por deficientes visuais no ensino de arte por meio da observação da prática de alguns professores. Verificou a necessidade e a importância da produção de textos e material visual como forma de estimular a troca de saberes entre a universidade e as escolas; bem como a importância do desenho como ferramenta para o estímulo cognitivo do aluno cego, auxiliando na sua percepção, motricidade e autonomia.

A pesquisa de cunho qualitativo das professoras de educação física (LIMA e ROCHA, 2010) objetivou analisar os caminhos para uma proposta metodológica em dança para pessoas cegas. Com a coleta de dados, diário de campo, observação participante, grupo focal, história de vida e vivências práticas, os pesquisadores encontraram elementos significativos como: consciência corporal, expressividade, vocabulário de movimento e improvisação, composição coreográfica, bem como possibilidades facilitadoras visando ao objetivo proposto.

A pesquisa ação do professor de arte (RABELLO, 2010) apresentou um balanço do atendimento ao aluno cego em escolas públicas de Salvador, quanto ao ensino de arte. Por meio de entrevistas realizadas com os professores de arte, o pesquisador identificou a necessidade de formação continuada dos docentes, a carência de experiências de inclusão bem sucedidas em escolas públicas e privadas, a precariedade na orientação dada pelo professor de arte à educação do aluno cego.

A professora de arte (SILVA, 2010) objetivou realizar uma reflexão sobre a fruição da pessoa cega e as informações imagéticas advindas do teatro pelos usuários cegos. Para tal, a pesquisadora discute sobre o conceito de audiodescrição, tecnologias assistivas para eliminação de barreiras e a efetivação de práticas inclusivas respaldadas pela legislação. (SILVA, 2010) conclui que a audiodescrição é a tecnologia assistiva e educacional que ajuda a diminuir as distâncias e democratizar o acesso à informação no teatro.

A pesquisa da professora de arte (FREITAS, 2012) objetivou relatar a própria experiência como docente do Curso de Pedagogia da Universidade do Estado da Bahia (UNEB) após o ingresso de uma aluna cega no curso. A pesquisadora visou à produção de materiais que permitissem à aluna a vivência plástica e fruição de imagens de obras da História da Arte. Por meio da idealização do projeto “Tocar para ver", a pesquisadora verificou o potencial da arte como instrumento de educação, cultura e inclusão. 
Por meio da pesquisa participante, a professora de educação física (MOTA, 2012) analisou a metodologia do ensino de dança empregado pelo grupo "Passos para luz", com nove anos de atuação na cidade de Belém/PA, cujos integrantes são pessoas cegas. (MOTA, 2012) conclui que a dança e a metodologia do grupo, trabalhada por unidades elementares de desenvolvimento de movimentos e deslocamentos do corpo no espaço (como andar, movimentos circulares, giros, resistência, torção, saltos e expressão facial), contribuem de forma significativa para a ressignificação das possibilidades artísticas e a importância de se pensar novos meios de ensino da dança para a pessoa cega.

A professora de arte (NÓBREGA, 2012) analisa as possibilidades de mediação da audiodescrição como recurso facilitador ao acesso às imagens por parte da pessoa cega em espetáculos teatrais. A pesquisadora conclui que a audiodescrição, além de funcionar como tecnologia assistiva, contribui para a formação do espectador e para a aquisição da linguagem teatral pelo cego.

\subsection{ALGUMAS CONSIDERAÇÕES SOBRE A PRODUÇÃO LEVANTADA}

A revisão bibliográfica procurou levantar produções que relacionassem o ensino de arte para o aluno cego na escola comum, verificando os principais objetivos, metodologias e resultados. Nos anais da ANPED, apenas um trabalho foi encontrado em contexto escolar nos últimos doze anos, produzido por um professor de arte e publicado no GT 15 (Educação Especial) da ANPED. O levantamento do banco da CAPES demonstrou que as produções, em sua maioria, foram realizadas em escola especial, em museus e apenas uma em escola comum. Ao todo são oito dissertações de mestrado e uma tese de doutorado, sendo quatro dissertações realizadas por professores de arte. O levantamento da SCIELO demonstrou que, entre as três produções encontradas, duas foram propostas por uma mesma professora de arte. $\mathrm{O}$ levantamento demonstrou ainda que as produções foram realizadas em clínicas e hospitais e apenas uma considerou o ensino de arte na escola comum. Nos anais do CONFAEB, das vinte duas produções encontradas, quatorze foram elaboradas por professores de arte e apenas dez apresentam a escola como contexto de investigação.

Quanto à deficiência pesquisada, o levantamento, de forma geral, indica maior quantidade de produções em torno da deficiência intelectual e discussões em torno da inclusão. Mesmo que o aluno com deficiência na escola comum e o cotidiano docente para 
com esses alunos sejam a tônica das politicas públicas (CF, art. 208 inc.III; LDB, nº394/96, art.58), de documentos internacionais (Declaração de Salamanca 1994) e discussões educativas dos últimos tempos, ainda, a produção de pesquisas e estudos envolvendo o ensino de arte e a educação especial na escola é escassa. Parece que o professor de arte não divulga a sua prática e a de seus pares. (REILY, 2010, p.82) evidencia:

\begin{abstract}
Neste momento é preciso reconhecer que existe uma lacuna muito grande entre a prática em arte com públicos especiais e a produção de literatura sobre o assunto. Não chega a uma dezena o número de livros publicados no Brasil que abordam os fazeres em artes plásticas com pessoas com deficiência, entre os quais constam Bavcar (2003), Reily (1986, 2001), Francisquetti (2005) e Lopes (2008).
\end{abstract}

O levantamento aponta ainda para a incidência do termo "inclusão escolar" presente nos trabalhos, não ficando muito clara sua distinção com a educação inclusiva e com a educação especial, pois não seriam sinônimos. Segundo (BUENO, MENDES e SANTOS, 2008, p.49), “inclusão escolar refere-se a uma proposição política em ação, de incorporação de alunos que tradicionalmente têm sido excluídos da escola, enquanto que educação inclusiva refere-se a um objetivo político a ser alcançado".

Ficou evidente a ausência de materiais adaptados nas aulas de arte, pouca articulação entre os professores de arte com o serviço ao atendimento educacional especializado, pouca discussão sobre a cegueira no espaço escolar e a presença de atividades aleatórias e sem relação com o restante do grupo. O aluno cego, por não ter acesso aos recursos e à mediação verbal adequada, não se apropria dos conhecimentos em igualdade.

Apesar de se discutir tanto sobre uma escola para todos, parece ainda não existir na organização da escola e dos que nela atuam, articulação coletiva tanto prática quanto teórica para se pensar a educação comum com a educação do aluno especial. O levantamento realizado demonstra que o ensino de arte para a educação especial se encontra atrelado em contextos clínicos e especializados e não na escola comum. (REILY, 2009) mapeou dissertações e teses brasileiras do banco de teses da CAPES e de bibliotecas de universidades dos 35 anos anteriores que dialogam os temas referentes à arte e deficiência e constatou que esta área ainda é um ramo em formação. 
A pesquisadora encontrou 32 pesquisas que abordam a arte e a deficiência e evidencia que, entre os 26 pesquisadores interessados em discutir a temática, metade são professores de arte, sendo que cinco deles apresentam deficiência. Entre os assuntos mais discutidos se encontram a formação de professores cujas licenciaturas ainda demoram em se adequar à nova configuração da sala de aula perante a diversidade que se acentuou. (REILY, 2009) observa ainda que os pesquisadores do campo da arte e deficiência se mostram tímidos quando o tema é a inclusão no contexto escolar.

Verificou-se, pelos levantamentos, a necessidade de diretrizes distintas daquelas que orientam as práticas no campo da medicina que se consolidaram historicamente, enquanto que as bases sobre arte e deficiência ainda estão em etapa de definição. As produções acadêmicas em arte precisam ser divulgadas e socializadas para então fornecerem suporte para pesquisas futuras que se articulam com a proposta da educação inclusiva. A divulgação e a socialização sobre o tema podem proporcionar mudanças significativas na área, visibilidade, bem como a maneira com que a sociedade percebe os direitos das pessoas com deficiência.

O levantamento demonstra uma carência muito grande no que se refere a pesquisas sobre o ensino de arte no contexto da educação especial o que prejudica a própria área de conhecimento. Por outro lado, evidencia a preocupação dos pesquisadores em arte por caminhos metodológicos que viabilizem a prática do ensino dessa disciplina para o aluno cego como os objetos pedagógicos adaptados, tátil e em relevo, tecnologias assistivas e recursos de acessibilidade.

A abordagem e os instrumentos qualitativos (observações, notas de campo, documentos, entrevistas, oficinas e narrativas orais) foram abundantes, de forma geral, em praticamente todos os trabalhos que relacionaram arte e deficiência. As pesquisas revelaram fatos importantes sobre o interior da escola, evidenciando um problema social delimitado pela política atual. Sobre isso (GARCIA, 2008, p.20 e 21) postula:

A ideia de inclusão escolar que está sendo base para as políticas educacionais tem uma matriz liberal, a qual tenta obscurecer as diferenças de classe social. No exercício discursivo e político de inclusão, observa-se a incorporação ou rearranjo de novos/velhos conceitos que apoiam a manutenção de concepções já conhecidas e consagradas como incapazes de apoiar processos satisfatórios de 
escolarização de alunos com deficiências com sentidos relacionados a acesso, permanência e possibilidade de sucesso escolar no que se refere ao desenvolvimento de interações que promovam o desenvolvimento humano e que necessariamente envolvem a apropriação dos conhecimentos historicamente organizados e considerados como conhecimento escolar.

É necessário que as informações coletadas sejam confrontadas e relacionadas com a vivência escolar e o meio social sem desconsiderar as condições econômicas, sociais e culturais para que não acabem se tornando apenas fatos ou fenômenos isolados. Nesse aspecto, uma abordagem que privilegie uma análise de caráter mais amplo incidiria numa melhor compreensão do objeto pesquisado e dos dados empíricos coletados.

Nessa linha, (GÓES, 2008) aponta algumas discussões em torno das possibilidades do educando e das responsabilidades do meio social na esfera da educação para pessoas com deficiência, fazendo com que a abordagem histórica materialista tenha destaque nas contribuições a esse respeito por possibilitar uma sólida compreensão propositiva pela visão que assume sobre o desenvolvimento do indivíduo e o meio em que ele se desenvolve.

Muitas contribuições se encontram nos estudos de (VYGOTSKY, 1995) e o levantamento aqui realizado as apresentam principalmente nos trabalhos dos professores de arte. (VYGOTSKY, 1995) evidencia que a cegueira é superada mais pela palavra e pelo universo conceitual do que pela compensação multissensorial em si, que a leitura e a escrita possibilitada pelo alfabeto braile têm maior relevância que o tato e, portanto, a ação educativa deve ser orientada para a conquista de atividades relevantes de forma a contribuírem com a capacidade de significar e pensar o mundo. Destaca-se que, nesta pesquisa, optou-se por realizar um exercício de investigação que pudesse direcionar a análise, considerando a relação entre a educação especial e o ensino da arte com os determinantes mais amplos envolvendo educação e sociedade. Empreendeu-se um esforço no sentido de compreender o ensino de arte para os alunos cegos no contexto da sociedade atual, apontando os direcionamentos políticos, pedagógicos e a realidade escolar. 


\section{REFERENCIAS}

\section{TRABALHOS APRESENTADOS EM EVENTO}

ALMEIDA, M. O. Contribuições da perspectiva educacional de Helena Antipoff para o ensino de arte em Minas Gerais: Fazenda do Rosário (1940-1970). In: XXI CONFAEB, 2011, São Luis. Anais 2. Textos Completos, XXI CONFAEB, 2011.

ALVES, J. F. . Por um olhar para além da visão: fotografia e cegueira. In: $34^{\text {a }}$ Reunião Anual da ANPED, 2011, Natal/RN. 34ª Reunião Anual - Anais 2011. Rio de Janeiro: Anped, 2011.

AMARAL, M. V. N. do; FREITAS, A. M. M. ; Vitória . Educação e artes aliadas para inclusão de educandos surdos. In: $18^{\circ}$ Congresso da Federação de arte/educadores do Brasil, 2007, Florianópolis. $18^{\circ}$ Congresso da Federação de arte/educadores do Brasil, 2007.

ARAUJO, C. M.; SILVA, E. M. A. Tendências e concepções do ensino de arte na educação escolar brasileira: um estudo a partir da trajetória histórica e sócio-epistemológico da Arte/Educação. In: $30^{\mathrm{a}}$ Reunião Anual da ANPED, 2007, Caxambu. Anais, 2007.

BARBOSA, Ana Mae. Arte-educação contemporânea ou culturalista. In: Trajetória e Políticas para o Ensino das Artes no Brasil: Anais do XV Confaeb / José Mauro Barbosa Ribeiro (organizador). Brasília: Ministério da Educação, 2009. (p.61-70)

BATISTA, M. F. S. ; Maria Christina de Souza Lima Rizzi. Museu da Imagem e do Som: Iniciativas de Inclusão. In: VII Seminário do Ensino de Arte do Estado de Goiás: Desafios e Possibilidades Contemporâneas e CONFAEB - 20 anos., 2010, Goiânia, GO. Anais do VII Seminário do Ensino de Arte do Estado de Goiás: Desafios e Possibilidades. Goiânia, GO: CONFAEB, 2010. v.1. p.20872097.

CIRILlO, A. J.; COSTA, R. P. F. ; RODRIGUES, R.. A Cidade e seus fluxos: artes e cultura na educação especial. In: CONFAEB 20: indivíduos/coletivos/comunidades/redes, 2010, Goiânia. Anais do VII Seminário do Ensino de Arte do Estado de Goiás: Desafios e Possibilidades. Goiânia: UFGO, 2010. v. 1. p. 1637-1645.

COSTA, R. X.. Ensino de arte e educação inclusiva. In: $18^{\circ}$ CONFAEB - Congresso Nacional da Federação de Arte-Educadores do Brasil, 2008, Crato - CE. Anais do $18^{\circ}$ CONFAEB. Crato - CE: CPD/URCA, 2008. v. 1.

FERNANDES, V. L. P.. Criatividade e educação inclusiva no ensino de artes visuais. In: Congresso Latino-Americano e Caribenho de Arte/educação, $19^{\circ}$ Congresso Nacional da Federação de Arte-educadores do Brasil, Encontro Nacional de Arte/educação, Cultura e Cidadania, 2009, Belo Horizonte. Anais. Belo Horizonte, 2008. v. 1. p. 1-9.

FREITAS, A. C. O.. Tocar para ver: Relato de experiência - Artes Visuais, com foco na pessoa com deficiência. In: Arte/Educação: Corpos em Trânsito, 2012, São Paulo. Arte/Educação: Corpos em Trânsito: anais do XXII CONFAEB, 2012. 
GOMES, A. L. L. A coerência textual de alunos com síndrome de Down: uma análise da produção escrita através do uso de imagens. In: $35^{\text {a }}$ Reunião Anual Anped, 2012, Porto de Galinhas. Educação, cultura, pesquisa, pesquisa e projetos de desenvolvimento: o Brasil do século XXI, 2012. v. único. p. $1-20$.

GOMES, E. S. M.; ISHII, B. I.; MORAES, J. L.; OLIVEIRA, P. C. B.; TOMASULO, A. I.. O coral cênico da APAE de Mogi das Cruzes: $O$ fazer artístico como elemento de inclusão social. In: Arte/Educação: Corpos em Trânsito, 2012, São Paulo. Arte/Educação: Corpos em Trânsito: anais do XXII CONFAEB, 2012.

KIRST, A. C.; SILVA, M. C. R. F.. Educação inclusiva e arte: A construção de uma trajetória. In: XXI CONGRESSO DA FEDERAÇÃO DE ARTE EDUCADORES, 2011, Florianópolis. Anais do XXI Congresso da Federação de Arte Educadores do Brasil. Maranhão: Editora UFMA, 2011. p. 0111.

KOHATSU, L. N. A expressão fotográfica de uma jovem com Síndrome de Down. In: $23^{\mathrm{a}}$ Reunião Anual da ANPED - Associação Nacional de Pós-graduação e Pesquisa em Educação, 2000, Caxambu. Educação Não É Privilégio. Caxambu - MG: ANPED, 2000.

LIMA, M. D. ; Rocha, D. D. . Dançando a corporeidade da pessoa com deficiência visual: um relato de experiência a partir da pesquisa ação. In: VII Seminário do ensino de arte do estado de Goiás e CONFAEB (20 anos), 2010, Goiânia. VII Seminário do ensino de arte do estado de Goiás e CONFAEB, 2010.

LIMA, M. D.; TERRA, A. M.; TONIETTI, D. F.. Trabalhando com a dança na escola na perspectiva da inclusão. In: VII Seminário do ensino de arte do estado de Goiás e CONFAEB(20 anos), 2010, Goiânia. VII Seminário do ensino de arte do estado de Goiás e CONFAEB, 2010.

LOPES, A. E. R. C. Ato fotográfico e processos de inclusão: uma análise dos resultados de uma pesquisa-intervenção. In: $28^{\circ}$ Reunião da ANPED Associação Nacional de Pós-graduação e Pesquisa em Educação, 2005, Caxambu/MG. 28 Reunião ANPED, 2005.

MENEZES, F.A.O.; SILVA, J. J.. Arte na educação especial: Experiências e possibilidades. In: XXI Congresso Nacional da Federação de Arte Educadores do Brasil/ CONFAEB, 2011, São Luís. Anais 1: Livro de Programação e Resumos, 2011.

NÓBREGA, A. Mediação inclusiva: a áudio-descrição abre as cortinas do teatro para pessoa com deficiência visual. In: Arte/Educação: Corpos em Trânsito, 2012, São Paulo. Arte/Educação: Corpos em Trânsito: anais do XXII CONFAEB, 2012.

OLEQUES, L. C. Ensino da arte: Ensinando desenho a crianças com deficiência Intelectual. In: Arte/Educação: Corpos em Trânsito, 2012, São Paulo. Arte/Educação: Corpos em Trânsito: anais do XXII CONFAEB, 2012.

PUCCETTI, R.. Arte-educação e inclusão: Por um olhar diferente. In: VII Seminário do ensino de arte do estado de Goiás e CONFAEB(20 anos), 2010, Goiânia. VII Seminário do ensino de arte do estado de Goiás e CONFAEB, 2010.

Perfil e formação do professor de arte de Londrina: O desafio da educação inclusiva. In: Arte/Educação: Corpos em Trânsito, 2012, São Paulo. Arte/Educação: Corpos em Trânsito: anais do XXII CONFAEB, 2012. 
QUEIROZ, A. K. G.. Arte como ferramenta de inclusão social e educacional. In: Congresso Latino-americano e Caribenho de Arte/educação, $19^{\circ}$ Congresso Nacional da Federação de Arteeducadores do Brasil, Encontro Nacional de Arte/educação, Cultura e Cidadania, 2009, Belo Horizonte. Anais. Belo Horizonte, 2008.

RABELLO, R. S.. Ensino de arte e educação inclusiva: atendimento ao aluno com deficiência visual em escolas públicas de Salvador. In: VII Seminário do ensino de arte do estado de Goiás e CONFAEB(20 anos), 2010, Goiânia. VII Seminário do ensino de arte do estado de Goiás e CONFAEB, 2010.

REILY, L. Nas margens dos manuscritos e da vida: representações de deficientes em iluminuras medievais. In: 32 ${ }^{\mathrm{a}}$ Reunião Anual da Anped, 2009, Caxambu. Sociedade, cultura e educação: novas regulações? - ANPEd. Puc-Rio e Timbaúba, PE: ANPEd e Espaço Livre, 2009. v. 1. p. 1-15.

ROSA, Y. B. D. ; FISCHER, J. . Interação e inclusão de portadores de necessidades educacionais especiais (PNEE) por meio da arte. In: 28 $8^{\mathrm{a}}$ ANPED, 2005, Caxambu. $28^{\mathrm{a}}$ Reunião Anual Da ANPED, 2005.

SILVA, A. N. A.. Áudio-descrição: Tecnologia assistiva e educacional no teatro. In: VII Seminário do ensino de arte do estado de Goiás e CONFAEB(20 anos), 2010, Goiânia. VII Seminário do ensino de arte do estado de Goiás e CONFAEB, 2010.

SILVEIRA, T. S.; FISHER . Ela fica ali na sala de aula, os alunos fazem, ela ganha folha pra desenhar: inclusão escolar de educandos cegos em artes visuais. In: $32^{a}$ Reunião Anual da ANPED, 2009, Caxambu. Sociedade, cultura e educação: novas regulações?, 2009.

VALE, C.; REY, K. L. F.. Projeto dia: diversidade, inclusão e arte - um caminho possível em educação inclusiva. In: VII Seminário do ensino de arte do estado de Goiás e CONFAEB(20 anos), 2010, Goiânia. VII Seminário do ensino de arte do estado de Goiás e CONFAEB, 2010.

VILARONGA, I. Formação, cinema e áudio-descrição: Pode a Sétima Arte Influenciar no Processo Construtivo de Pessoas Visualmente Limitadas? In: 34 ${ }^{\mathrm{a}}$ Reunião Anual da ANPED, 2011, Natal. Educação e Justiça Social - ANPED, 2011.

\section{DISSERTAÇÕES E TESES}

ANASTASIOU, H. P.. Ensino e aprendizagem em artes visuais: Adultos com Síndrome de Down em Interação. Mestrado Acadêmico em Artes Visuais. UDESC, Santa Catarina, 2012.

BERNARDO, S. F.. A música na educação de pessoas com deficiência visual: Uma Experiência na Unidade Educacional Especializada José Álvares de Azevedo. Mestrado Acadêmico em Artes. UFPA, Pará, 2012.

BRUNO, M. M. G.. O significado da deficiência visual na vida cotidiana: Análise das Representações dos Pais- Alunos -Professores. Mestrado. UCDB, Campo Grande, 1999.

GARCIA, R. B.. A percepção de esculturas por três pessoas cegas. Mestrado Acadêmico em Educação, Arte e História da Cultura. MACKENZIE, São Paulo, 2012. 
LIMA, F. J.. O efeito do treino com desenhos em relevo no reconhecimento háptico de figuras bidimensionais tangíveis. Tese de doutorado. Ribeirão Preto: Faculdade de Filosofia, Ciências e Letras de Ribeirão Preto da USP, 2001.

MARCHEZI, F.. Acessibilidade em museus de arte: Questões para a elaboração de audioguias. Mestrado Acadêmico em Educação, Arte e História da Cultura. MACKENZIE, São Paulo, 2012.

MOTA, M. A.. O ensino da dança para o deficiente visual. In: Arte/Educação: Corpos em Trânsito, 2012, São Paulo. Arte/Educação: Corpos em Trânsito: anais do XXII CONFAEB, 2012.

NERES, C. C.. Educação profissional do portador de necessidades especiais para quê? (O caso de Campo Grande - MS). 1999. 208p. Dissertação (Mestrado em Educação) - Universidade Federal de Mato Grosso do Sul, Campo Grande, 1999.

MATTOSO, V. A.. Ora, direis, ouvir imagens? Um olhar sobre o potencial informativo da áudiodescrição aplicada a obras de artes visuais bidimensionais como representação sonora da informação em arte para pessoas com deficiência visual. Mestrado Acadêmico. UFRJ, Rio de Janeiro, 2012.

OLIVEIRA, U. T.. A importância da arte na inclusão escolar e no desenvolvimento de pessoas com necessidades educativas especiais - deficiência intelectual. Mestrado Acadêmico. UFES, Espírito Santo, 2012.

SIMÓ, C. H.. O estado da arte nas teses acadêmicas que abordam arte e inclusão: Um recorte de 1998 a 2008 no Brasil. Mestrado Acadêmico em Artes Visuais. UDESC, Santa Catarina, 2010.

TOJAL, A. P. F.. Políticas públicas culturais de inclusão de públicos especiais em museus. Tese de Doutorado. Escola de Comunicação e Artes - USP, São Paulo, 2007.

VERAS, C. A. A.. A arte Down: A Educação Especial e a Cultura Amazônica. Mestrado Acadêmico em Comunicação, Linguagens e Cultura. UNAMA, Amazonas, 2012.

\section{ARTIGO EM PERIÓDICO}

BARRA, A. S. B. . Marxismo e a produção do conhecimento científico. Revista Urutágua (Online), Maringá, Paraná, v. 11, p. 15-30, 2006.

BOSCOLO, C. C.; PINOTTI, K. J.. A dramatização como estratégia de aprendizagem da linguagem escrita para o deficiente auditivo. Revista Brasileira de Educação Especial, v. 14, p. 121140, 2008.

GARCIA, R. M. C. Política de educação especial na perspectiva inclusiva e a formação docente no Brasil. Revista Brasileira de Educação (Impresso), v. 18, p. 101-119, 2013.

KASSAR, M.C.M. Educação especial na perspectiva da educação inclusiva: desafios da implantação de uma política nacional. Educar em Revista (Impresso), v. 41, p. 61-79, 2011.

MENDONÇA, E. S. . O útil e a obra de arte em Marx e Heidegger. Griot Revista de Filosofia, 21 dez. 2010. 
NERES, C. C; CORRÊA, N. M.. O trabalho como categoria de análise na educação do deficiente visual. Cadernos CEDES (Impresso), v. 1, p. 149-170, 2008.

REILY, L. Músicos cegos ou cegos músicos: representações de compensação sensorial na História da Arte. Cadernos CEDES (Impresso), v. 28, p. 245-266, 2008.

O ensino de artes visuais na escola no contexto da inclusão. Cadernos CEDES (Impresso), v. 30, p. 84-102, 2010.

\section{DOCUMENTO COM AUTORIA DE IDENTIDADE}

BRASIL. Constituição (1988). Constituição da República Federativa do Brasil. Brasília, DF: Senado Federal: Centro Gráfico, 1988. 292 p.

Lei de Diretrizes e Base da Educação Nacional 9.394/96. Disponível em:

<http://www.planalto.gov.br/ccivil_03/LEIS/19394.htm>. Acesso em: jun 2014.

\section{LIVRO}

BUENO, J. G. S.. Processos de inclusão/exclusão escolar, desigualdades sociais e deficiência. In: Denise Meirellles de Jesus; Claudio Roberto Baptista; Sonia Lopes Victor. (Org.). Pesquisa e educação especial: mapeando produções. $1^{a}$ ed. Vitória: Editora da Universidade Federal do Espírito Santo - EDUFES, 2006, v. 1, p. 105-1232.

. MENDES, G. M. L. ; SANTOS, R. A.. Deficiência e escolarização: novas perspectivas

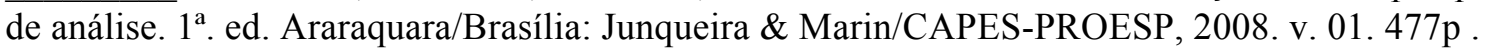

GARCIA, R. M. C. . Políticas inclusivas na educação: do global ao local. In: Claudio Roberto Baptista; Katia Regina Moreno Caiado; Denise Meyrelles de Jesus. (Org.). Educação especial: diálogo e pluralidade. $1^{\mathrm{a}}$ ed. Porto Alegre: Mediação, 2008, v. 1, p. 11-23.

GÓES, M. C. R. Contribuições da abordagem histórico-cultural para a pesquisa em educação especial. In: Batista, J.C.; Caiado, K.R.M.; Jesus, D.M.. (Org.). Educação Especial: diálogo e pluralidade. $1^{\mathrm{a}}$ ed. Porto Alegre: Mediação, 2008, v. 1, p. 37-46.

NUNES,A.L.R. Panorama da pesquisa em artes visuais em inter-relação com a inclusão. ISBN:9788561136215. In: Geovana Mendonça Lunardi Mendes; Maria Cristina da Rosa Fonseca (orgs). (Org.). Educação, Arte e Inclusão: Trajetórias de Pesquisa. $1^{\mathrm{a}}$ ed. Florianópolis/SC: Editora da UDESC/SC, 2010, v. 01, p. 01-212.

PADILHA, A. M. L. Quem pergunta precisa saber. Educação especial: diálogo e pluralidade. Porto Alegre: Mediação, 2008, v. 1, p. 185-193.

REILY, L. História, arte, educação: reflexões para a prática de arte na educação especial. In: Claudio Roberto Baptista; Katia Regina Moreno Caiado; Denise Meyrelles de Jesus. (Org.). Educação especial: diálogo e pluralidade. $1^{a}$ ed. Porto Alegre: Editora Mediação, 2008, v. 1, p. 221-239.

Pesquisas brasileiras sobre arte e deficiência: um campo de conhecimento em formação. In: Geovana Mendonça Lunardi Mendes; Maria Cristina da Rosa Fonseca e Silva. (Org.). Educação, 
arte e inclusão: trajetórias de pesquisa. $1^{\text {a }}$ ed. Florianópolis: Editora da UDESC, 2009, v. 1, p. 135153.

VYGOTSKY, L.S. El niño ciego . In: Obras completas. Tomo V, Habana: Cuba, 1989.

Fundamientos de defectologia. $2^{\text {a }}$ ed. Havana: Pueblo y Educación, 1995.

Recebido em 30 de maio de 2017 Aprovado em 25 de outbro de 2017 